\title{
FURTHER COMMENTS ON THE GENUS HEDWIGIA (HEDWIGIACEAE, BRYOPHYTA) IN RUSSIA
}

\author{
К ТАКСОНОМИИ РОДА НЕDWIGIA (HEDWIGIACEAE, ВRYOРНYТА) В РОССИИ \\ ELENA A. IGNATOVA ${ }^{1}$, OXANA I. KUZNETSOVA ${ }^{2} \&$ MiCHAEL S. IGNATOV ${ }^{1,2}$ \\ ЕЛЕНА А. ИГНАТОВА ${ }^{1}$, ОКСАНА И. КУЗНЕЦОВА ${ }^{2}$, МИХАИЛ С. ИГНАТОВ ${ }^{1,2}$
}

Abstract

\begin{abstract}
A new species from Asian Russia, Hedwigia kuzenevae sp. nova, is described based on integrative molecular and morphological study. It is similar to the recently described $H$. czernyadjevae in plant habit, highly recurved leaf margins and hair-point structure, but differs in multipapillose leaf cells. The latter character, as well as leaf margins recurved to the hair-point, correspond to H. ciliata; however, its hair-points are shorter, less strongly papillose, especially in distal part, and leaves are falcate-secund, contrary to the straight leaves of $H$. kuzenevae. Distribution area of $H$. kuzenevae includes Transbaikalia and Tukuringra Range in Amurskyaya Province; it is also known from few localities in Yakutia and Krasnoyarsk Territory. It often grows in areas with calcareous bedrocks. Another taxon, H. emodica var. echinata var. nova, is described from Asian Russia. It differs from the type variety in falcate-secund leaves and slightly shorter hair-points with sharply dentate margins and dorsal surface of hair-points covered with high, dense, branched spinulae. These morphological differences make these taxa quite distinct, though they are not separated from each other by nuclear ITS1-2 DNA marker, contrary to other taxa within Hedwigia. According to the DNA sequence data, Hedwigia mollis is also closely related to H. emodica, but it is better separated and likely deserves species status. It shares some morphological features with both varietes of $H$. emodica, but differs from both of them by shorter hair-points with sligtly papillose distal portion. Hedwigia emodica var. emodica has a widest distribution area throughout Russia, while H. mollis is mainly Eiuropean species and distribution of H. emodica var. echinata is restricted to the south of Russian Far East and Transbaikalia.
\end{abstract}

Резюме

На основе интегративного молекулярного и морфологического анализа из азиатской России описан новый вид, Hedwigia kuzenevae sp. nova. Он похож на недавно описанный вид $H$. czernyadjevae по облику растений, высоко отогнутым краям листа и длинным, сильно шероховатым гиалиновым волоскам, но отличается от него клетками с несколькими папиллами. Клетки с несколькими папиллами и высоко отогнутые края листа свойственны также H. ciliata, но у этого вида гиалиновые волоски менне сильно папиллозные, а листья односторонне обращенные. Hedwigia kuzenevae встречается в Забайкалье и Амурской области; единичные местонахождения известны из Якутии и Красноярского края. Вид растет в районах распространения карбонатных пород. Еще один таксон, H. emodica var. echinata var. nova, описан с юго-востока Азиатской России. От типовой разновидности он отличается односторонне обращенными листьями и гиалиновыми волосками с остро пильчатыми краями и с длинными, густыми шипиками на дорсальной поверхности. По морфологическим признакам эти разновидности четко различаются, но они не отделяются друг от друга по изученному молекулярному маркеру ITS1-2. Согласно данным по этому маркеру, Hedwigia mollis также близка к H. emodica, но лучше от нее отграничена и скорее заслуживает видовой статус. Она отличается от обеих разновидностей $H$. emodica более короткими гиалиновыми волосками с редкими и низкими папиллами в верхней половине. Hedwigia emodica var. emodica pacпространена по всей территории России, H. mollis встречается в европейской части и на Алтае, а H. emodica var. echinata известна только с юга российского Дальнего Востока и из Забайкалья.

KEYWORDS: mosses, taxonomy, new species, molecular phylogenetics, ITS

\footnotetext{
1 - Lomonosov Moscow State University, Biological Faculty, Geobotany Dept., Leninskie Gory Str. 1-12, Moscow 119234 Russia - Россия, 119234, Москва, Ленинские Горы, д. 1 стр. 12, Московский государственный университет, биологический факультет, кафедра геоботаники. E-mails: arctoa@list.ru \& misha_ignatov@list.ru

2 - Tsitsin Main Botanical Garden, Russian Academy of Sciences, Botanicheskaya Str., 4, Moscow 127276 Russia - Poсcия 127276 Москва, Ботаническая 4, ГБС РАН. E-mail: oikuznets@gmail.com
} 


\section{INTRODUCTION}

Hedwigia P. Beauv. is a taxonomically difficult genus with still poorly resolved taxonomy. A number of species and intraspecific taxa were described within it during 19th century, but they were considered as synonyms of $H$. ciliata (Hedw.) P. Beauv. since Brotherus (1925). The genus was revisited in the last decade of the $20^{\text {th }}$ century by Hedenäs (1994) and Buck and Norris (1996); it resulted in description of one new species from Europe, H. stellata Hedenäs, and raising of Californian endemic H. ciliata var. detonsa (M. Howe) Paris to a species rank. Later Biasuso (2007) described H. brevipilifera Biasuso from Argentina; she also recognized $H$. ciliata var. nivalis (Müll. Hal.) Hampe in addition to the most widespread in Argentina type variety, $H$. ciliata. Hedwigia was also revised by Dalton et al. (2013) for Sino-Hymalaya, who listed three species for this region, i.e., H. ciliata, H. stellata and H. emodica Hampe ex Müll. Hal. (=H. ciliata var. leucophaea Bruch, Schimp. \& W. Gümbel).

The first molecular-phylogenetic analysis of Hedwigia based on mitochondrial nad-5, plastid trnL-trnF and nuclear ITS1\&2 markers (Buchbender et al., 2014) confirmed a separate status of $H$. stellata and $H$. ciliata var. striata (Wilson) Bruch \& Schimp., so the latter taxon was raised to the species rank. However, it was shown that $H$. ciliata var. leucophaea Bruch \& Schimp. cannot be maintained in its current morphological circumscription because some specimens with morphological characters of this taxon are likely of hybrid origin; it was supposed that "the distinguishing characters can obviously be developed independently in some taxa of the Hedwigia ciliata complex". One cryptic species separated by molecular data but lacking the distinctive morphological characters was also mentioned.

An integrative molecular and morphological study of the genus Hedwigia in Russia (Ignatova et al., 2016) resulted in recognizing five species in its territory. The same DNA regions as in the analyzis of Buchbender et al. (2014) were used. It was shown that $H$. ciliata s. str. has rather restricted distribution in western part of European Russia, but it is totally absent in the Caucasus, Urals and Asian part of the country. Specimens from Asian Russia previously referred to $H$. stellata due to a single papilla per cell (Ignatov et al., 2000, 2006) turned to be unrelated to the European specimens of this species by molecular data; some distinctive morphological characters were also found. This taxon described under the name H. czernyadjevae Ignatova, Fedosov \& Ignatov was revealed in Transbaikalia, Khabarovsk Territory and Yakutia. Two other groups of specimens formed well-supported clades in the analysis of combined alignment of three DNA regions. First of them represented a species with a southern distribution in Russia (Black Sea coastal areas of the Caucasus, Zabaikalsky and Primorsky Territories); it was also found in collections from eastern regions of the U.S.A. Combination of a small size of plants and falcate-secund leaves with short hair-points constituted its morphological distinction. The second group of specimens, mainly from European Russia, alpine areas of the Caucasus and also from Altai Mts, was described as $H$. mollis Ignatova, Fedosov \& Ignatov. It was found to be distinct from $H$. ciliata $\mathrm{s}$. str. both by molecular data and morphology; however, its distinction from another taxon recognized in this study, H. emodica, appeared to be more problematic. Both $H$. mollis and $H$. emodica differ from $H$. ciliata in only shortly recurved margins at leaf base, leaf papillae with short, round at tips branches and smaller spores; the difference between each other referred mainly to hair-point length and density of papillae. In addition, some specimens from the Russian Far East closely related to $H$. emodica-group were discussed, but their taxonomic status remained unresolved due to insufficient data.

At the same time, other specimens with unknown character combination were revealed in Asian Russia in the course of preparing of taxonomic treatment of the genus Hedwigia for the "Moss flora of Russia". So, the present study aims to outline taxonomic status of these specimens and to clarify taxonomy in Hedwigia emodica-group.

\section{MATERIAL AND METHODS}

All collections from LE, MHA, MW, SASY, and some specimens from other herbaria were studied for their morphology. Selection of specimens for DNA studies was addressed mainly to the problems remained from the previous study for the eastern part of Russia, where some plants were left as Hedwigia sp. (Ignatova et al., 2016), and also to other plants from that area. Eight sequences of three taxa were newly obtained.

The nuclear ITS region was used in the present analysis alone as it provided the main phylogenetic signal in the previous studies (Buchbender et al., 2014; Ignatova et al., 2016). DNA extraction and amplification were done according to the laboratory protocols described in Gardiner et al. (2005). The newly obtained data were supplemented by sequences available in GenBank. Braunia alopecura (Brid.) Limpr. was used as outgroup. Totally 61 specimens were involved into the analysis. Vouchers of newly sequenced specimens and GenBank accession numbers are compiled in Appendix 1. Sequences were aligned using BioEdit (Hall, 1999). Bayesian analysis was conducted in MrBayes 3.1.2 (Ronquist et al., 2012) using the GTR $+\mathrm{G}$ model, for $50,000,000$ generations with sampling every 1000 generations. Three simultaneous runs were used. The first $25 \%$ of sampled trees were discarded for the burn-in. Maximum parsimony analysis was completed with Nona (Goloboff, 1994) within the Winclada shell (Nixon, 1999a, b), with bootstrap calculation with 2000 replications. 


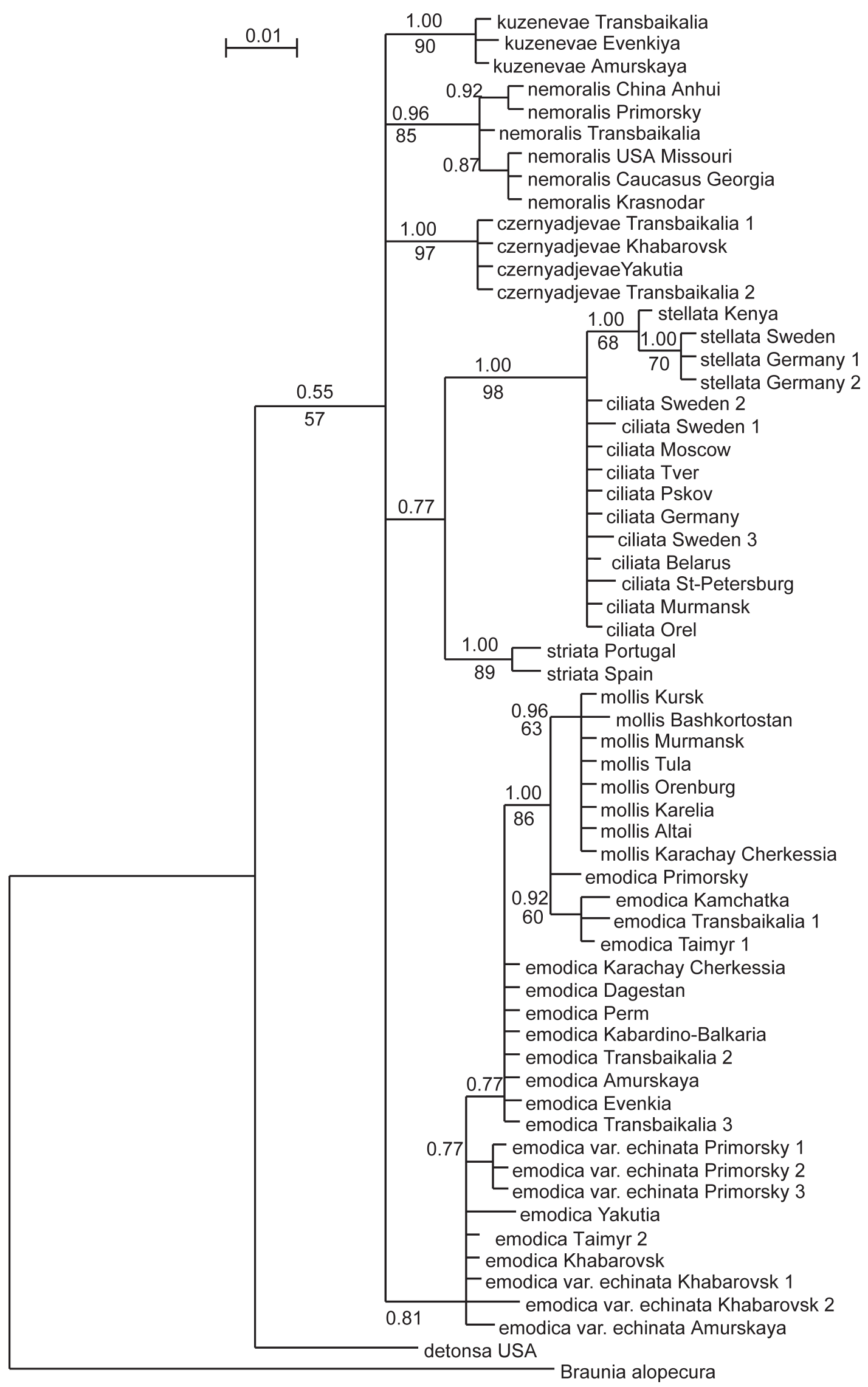

Fig. 1. Bayesian tree obtained from nuclear ITS1-2 sequences. Posterior probabilities $(>0.6)$ and Bootstrap supports $(>50)$ are indicated above and below branches. 
RESULTS

Phylogenetic tree from the Bayesian analysis of 60 specimens of Hedwigia rooted on one species of Braunia is shown in Fig. 1, where Bayesian posterior probabilities above 0.6 are shown and supplemented also by bootstrap support values from MP analysis, which has a similar topology with somewhat poorer resolution. American $H$. detonsa is sister to all other species of the genus in this phylogeny, where most groups are comprised in a wide polytomy of five smaller clades, the tree being monospecific and three formed of three taxa.

All three monospecific clades were found maximally or otherwise highly supported in Bayesian analysis and rather highly supported in MP analysis: $H$. czernyadjeviae $(\mathrm{PP}=1, \mathrm{BS}=97), H$. nemoralis $(\mathrm{PP}=0.96, \mathrm{BS}=85)$, and a new species described below, H. kuzeneviae $(\mathrm{PP}=1$, $\mathrm{BS}=90)$. The $H$. nemoralis clade comprises some geographic patterning: its subclades, albeit only moderately supported, represent (a) Caucasus + eastern North American subclade, and (b) Russian Far East + East China subclade, and Transbaikalian specimen of $H$. nemoralis is in a tritomy with these two subclades.

The $H$. ciliata $+H$. stellata $+H$. striata clade has only moderate support $(\mathrm{PP}=0.77)$, while two its subclades are hightly supported: $H$. striata $(\mathrm{PP}=1, \mathrm{BS}=89)$ is sister to the clade formed by two other species ( $\mathrm{PP}=1, \mathrm{BS}=98)$. Hedwigia ciliata forms a broad polytomy with nested clade formed by $H$. stellata and one specimen of $H$. ciliata from East Africa $(\mathrm{PP}=1, \mathrm{BS}=68)$, the latter being sister to terminal clade of $H$. stellata $(\mathrm{PP}=1, \mathrm{BS}=70)$.

The remaining specimens belong to the clade with moderate support of $(\mathrm{PP}=0.81)$, which includes a grade of $H$. emodica terminated with $H$. mollis $(\mathrm{PP}=0.96$, $\mathrm{BS}=63$ ). The basal part of this grade includes six specimens deviated in morphology and segregated below in a variety $H$. emodica var. echinata. In addition to morphology, both $H$. mollis and $H$. emodica var. echinata have a specific distribution, as the former occurs in the western part of Eurasia, whereas H. emodica var. echinata has a Far Eastern distribution.

\section{DISCUSSION}

Three specimens from Asian Russia (Amurskaya Province, Zabaikalsky and Krasnoyarsk Territories) are described below as $H$. kuzenevae sp. nova. They form a maximally supported clade without a definite relationship. Habitually, these plants are very similar to H. czernyadjevae by recurved leaf margins up to hair-point and long, slightly flexuose, densely spinulose on dorsal surface hair-points. However, their leaf laminae have several branched papillae per cell, contrary to single peltate papilla in each cell in $H$. czernyadjevae. Character combination of $H$. kuzenevae is similar to $H$. ciliata, but these two species do not show definite relationship in the molecular-phylogenetic analysis. Different ornamentation of hair-point dorsal surface constitutes their morphological distinction: in $H$. ciliata, hair-points are only sparsely and lowly papillose and follow a curvature of falcatesecund leaves, contrary to densely and highly spinulose, straight and slightly flexuose hair-points of $H$. kuzenevae. Also, $H$. ciliata has spores more than $30 \mu \mathrm{m}$ in diameter, whereas in $H$. kuzenevae it is $22-25 \mu \mathrm{m}$.

The nested position of Hedwigia mollis-clade and a clade of Far Eastern specimens in question within $H$. emodica grade agree with their morphology. All of them are separated from all other species known in Russia by leaf margins narrowly recurved only in the lowermost leaf portion and flat in distal 4/5-2/3. Hedwigia emodi$c a$ is also characterized by straight leaves and straight, long hair-points constituting (26-)32-47\% of leaf length; hair-point margins are subentire or weakly denticulate and dorsal surface is covered by papillae and moderately dense simple and branched spinulae. Both $H$. mollis and Far Eastern specimens differ from it in having regular sharp teeth along hair-point margins; such teeth are very rarely observed in $H$. emodica (seen in two specimens from the Caucasus). Hedwigia mollis and Far Eastern specimens represent different trends in leaf and hair-point morphology. In H. mollis, leaves mainly remain straight, but hair-points are often slightly recurved; rarely leaves are slightly secund (observed in specimens from Altai and Caucasus). Hair-points are shorter than in H. emod$i c a$, being (11-)16-33\% of leaf length. In addition, sculpture of hair-point dorsal surface changes from lower portion, covered with papillae and dense, moderately high, simple and branched spinulae, to the upper $1 / 2-1 / 3$, which is sparsely and lowly papillose; in case of forms with shorter hair-points, the latter are weakly papillose throughout. At the same time, Far Eastern specimens in question are immediately separated from both $\mathrm{H}$. emodica and $H$. mollis by strongly falcate-secund leaves. Their hair-points follow leaf curvature; they are comparable or slightly shorter than in $H$. emodica $(20-41 \%$ of leaf length) and are covered with longer, strongly branched, dense spinulae, also making hair-point margins ciliate in addition to sharp, narrow, sometimes hooked teeth.

Summing up, the "typical" plants of $H$. emodica, $H$. mollis and Far Eastern specimens are easily recognized by morphology. H. emodica seems to be rather uniform in morphology, though it is somewhat variable in studied DNA regions, being represented by an unresolved grade and two subclades within it. Two other taxa demonstrate some variability in particular morphological characters, causing some difficulty in identification of morphologically deviating specimens. The obtained topology suggests a possibility to recognize $H$. emodica s.l. and three varieties within it; it is also possible to recognize three separate species. In our opinion, total merging of all taxa within $H$. emodica is inappropriate, because it contains three entities with different, though occasionally overlapping morphology, different ecology and geography. At the same time, specimens of $H$. mollis form a moderately supported clade within $H$. emodica, while 

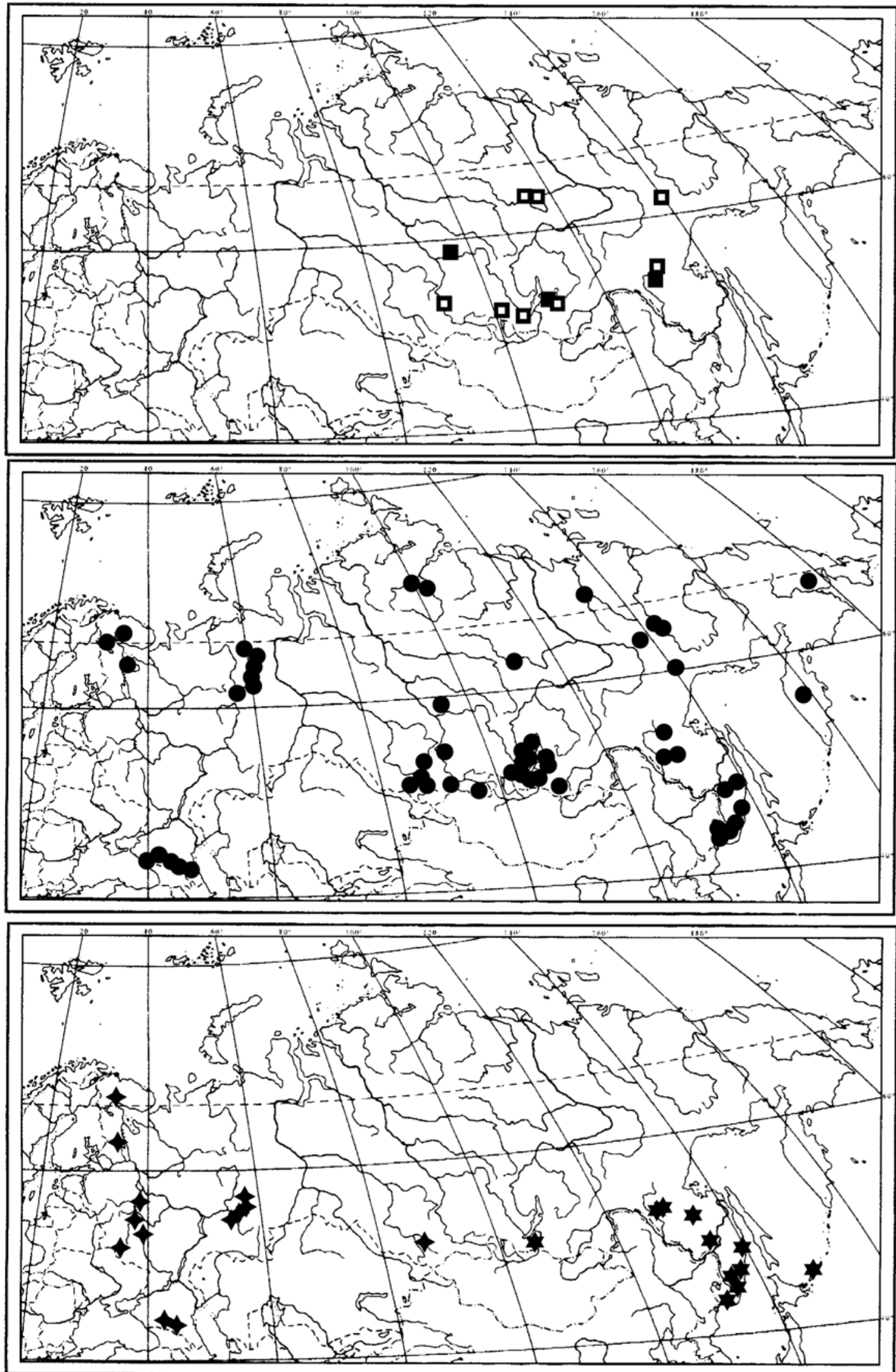

Fig. 2. Distribution of the species of Hedwigia in Russia and adjacent countries. Hedwigia kuzenevae: solid squares - sequenced specimens, hollow squares - other specimens; H. emodica: circles; $H$. mollis: four-pointed stars; H. emodica var. echinata: six-pointed stars. 

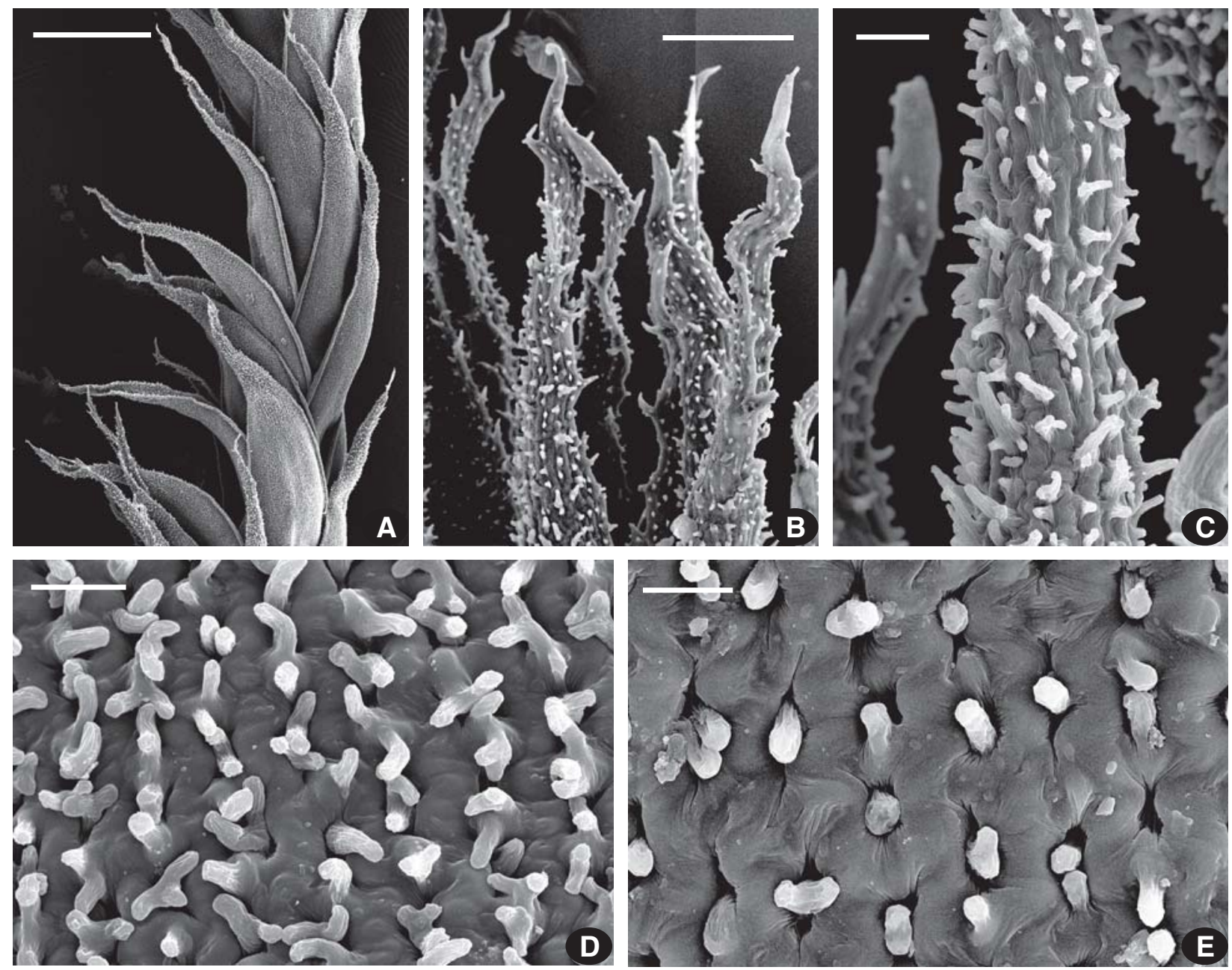

Fig. 3. Hedwigia kuzenevae (from: Krasnoyarsk Territory, Evenkia, 27.VI.1992, Shcherbina 121, MW). A-E (SEM). A-B: apical parts of leaves; C: dorsal surface of hair-point; D: papillae in mid-leaf on abaxial leaf surface; E: papillae in mid-leaf on adaxial leaf surface. Scale bars: $0.5 \mathrm{~mm}$ for A, $100 \mu \mathrm{m}$ for B; $20 \mu \mathrm{m}$ for C; $10 \mu \mathrm{m}$ for D, E.

Far Eastern specimens are less separated genetically and its clade has no support. We prefer to recognize $\mathrm{H}$. mollis as a separate species and H. emodica with two varieties, var. emodica and var. echinata var. nova (described below). However, further study of expanded specimen set from other geographical regions is needed for better understanding of the taxonomy in this group.

\section{TAXONOMY}

Hedwigia kuzenevae Ignatova \& Ignatov sp. nova

Type: Russia, Siberia, Zabaikalsky Territory, Chita District, Daursky Mt. Range, Aratsa Creek - a tributary of Ingoda River, 51 $54^{\prime} 50^{\prime}$ N, $114^{\circ} 25^{\prime} 06^{\prime} \mathrm{E}, 970 \mathrm{~m}$ alt., rock outcrops in larch forest, on rock; 13.VII.2012, Czernyadjeva 2-12 (Holotype LE, isotypes MHA and MW).

Diagnosis. The new species is most similar to Hedwigia czernyadjevae in straight leaves with leaf margins recurved up to hair-point and long, slighly flexuose, strongly papillose and spinulose on dorsal surface hairpoints; their main distinctive character is multipapillose vs. uniopapillose laminal cells. The distinction of $H$. kuzenevae from $H$. ciliata includes straight vs. falcatesecund leaves and densely spinulose throughout vs. distantly and lowly papillose in distal portion dorsal surface of hair-points.

Etymology. The species name is given in honour of Olga I. Kuzeneva (1887-1978), Russian botanist, who studied vascular flora, but also collected bryophytes, particularly in Amurskaya Province, including numerous specimens of the species being described.

Description. Plants greyish-green or brownish-green in distal part, greyish-brown proximally, in loose, easily disintegrated tufts. Stems up to $5 \mathrm{~cm}$ long, irregularly branched. Leaves erect, appressed when dry, widely spread when wet, 1.6-1.8×0.7-0.8 mm, with width/length ratio $0.44-0.46$, ovate and gradually narrowing to the apex 'or attenuate, concave; margins recurved in proximal 3/4 or up to the hair-point base; hair-points $0.5-0.7$ $\mathrm{mm}$ long, constituting 35-42\% of leaf length; margins of hair-points with long, sharp teeth, on dorsal surface with dense simple papillae and dense branched spinulae; apical cell moderately long, pointed, smooth or low- 


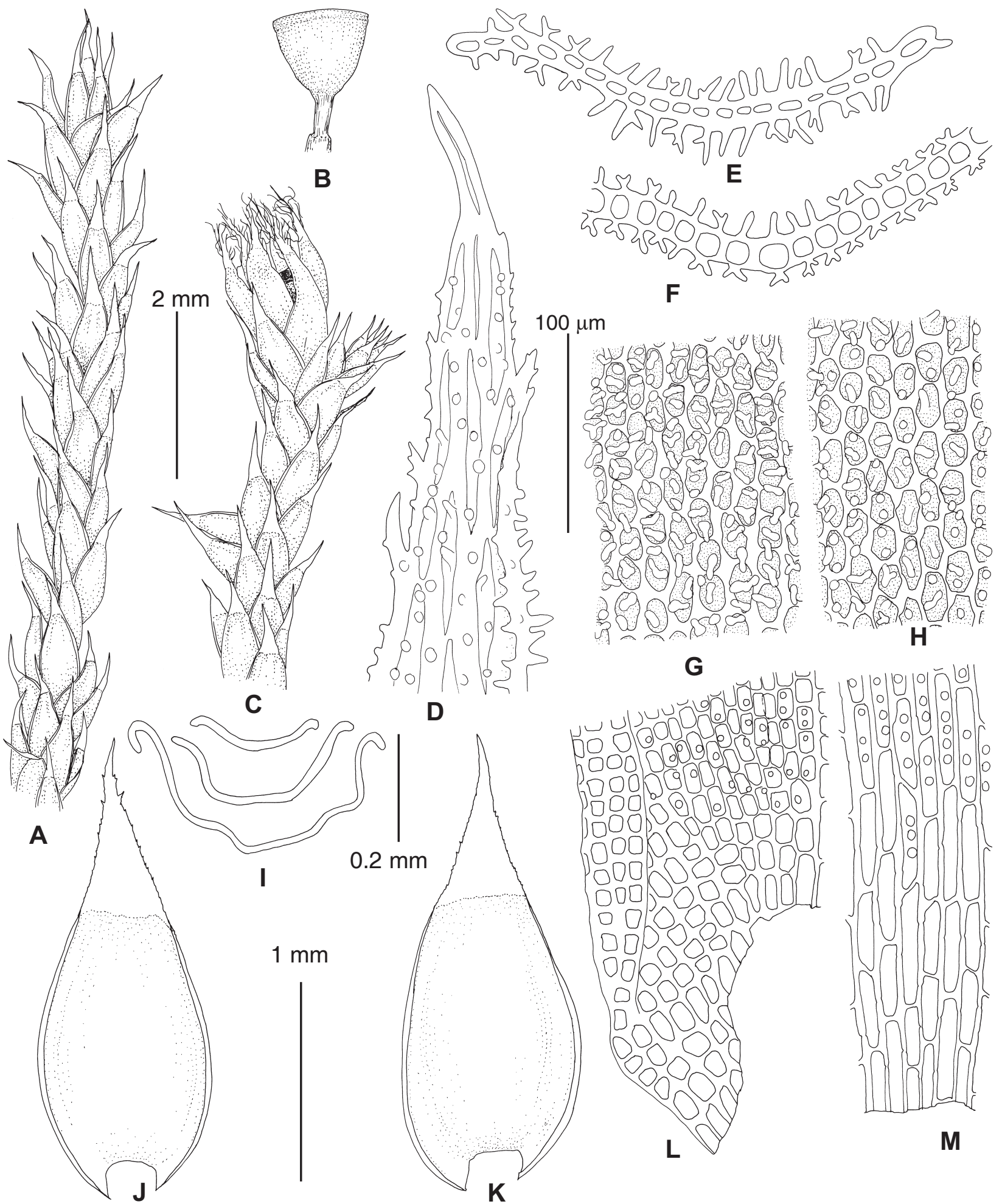

Fig. 4. Hedwigia kuzenevae (from holotype). A, C: habit, dry; B: capsule; D: hair-point; E-F, I - leaf transverse sections; G: median laminal cells om abaxial surface; H: median laminal cells om adaxial surface; J-K: leaves; L: basal marginal cells; M: basal cells in the middle of leaf base. Scale bars: $2 \mathrm{~mm}$ for A-C; $1 \mathrm{~mm}$ for J-K; $0.2 \mathrm{~mm}$ for I; $100 \mu \mathrm{m}$ for E-H, L-M.

ly papillose; median laminal cells (10-) $12-20 \times 10-12 \mu \mathrm{m}$, with thick, sinuose longitudinal walls with few pores, on abaxial surface with 2-4 high branched papillae per cell, on adaxial surface with 2-4 high, simple and branched papillae per cell; cells in the middle of leaf base linear,
30-60×12-14 $\mu \mathrm{m}$, porose, orange-brown, lowermost cells smooth, then gradually becoming papillose upwards, with several simple papillae per cell, gradually transiting into median leaf cells with branched papillae; basal marginal cells quadrate and short-rectangular, with non-porose 
transverse walls. Perichaetial leaves oblong, ca. $2.5 \times 0.8$ $\mathrm{mm}$, hyaline hair-point ca. $0.5 \mathrm{~mm}$, with long cilia. Capsules cup-like, 0.9-1.1 $\times 0.9-1.1 \mathrm{~mm}$, widest at the mouth; exothecial cells in the middle part of urn rectangular or short-rectangular, at urn mouth smaller in several rows. Operculum lowly conical, with low central mammilla. Spores 22-25 $\mu \mathrm{m}$, on distal surface with vermicular ridges. Calyptrae hairy in lower portion.

Distribution and ecology. Most numerous collections of Hedwigia kuzenevae are known from Tukuringra Mt. Range in Amurskaya Province (including territory of Zeya State Reserve) and between Zeya and Toko Lake in southern Yakutia. In Zabaikalsky Territory it was found, apart of the type locality in Chita District, in Nerchinsk surroundings. There is one specimen from Irkutsk Province, bear SW shore of Baikal Lake (Slyudyanka District). West of Baikal Lake, it was collected in Buryatia, inTunka Depression (old collections of early 20th century). There are also few collections from Yenisey River basin: near Krasnoyarsk City ("Krasnoyarsk Pillars" area) and along Podkamennaya Tunguska River and its tributary. In Yakutia, this species was found in Suntar District (Vilyui River basin) and in Sette Daban Mt. Range. Grows at 340-1400 $\mathrm{m}$ a.s.l., on rocks in larch and birch forests, rarely in mountain tundra, on rock-fields and on dry cliffs along creeks.

Specimens examined: ASIAN RUSSIA: Krasnoyarsk Territory: Krasnoyarsk City surroundings, "Krasnoyarsk Pillars" area, 24.VI.1935, Vereshchagin s.n. (LE); Evenkia, Baikit District: Podkamennaya Tungiska at ca. $90 \mathrm{~km}$ upstream its mouth, ca. 61³0'N, 91²0'E, "Shcheki" area, 8.VII.1994, Shcherbina 274 (MW); Stolbovaya Creek $1 \mathrm{~km}$ upstream its mouth, ca. 62 ${ }^{\circ}{ }^{\prime} \mathrm{N}, 91^{\circ} 9^{\prime} \mathrm{E}$, “Pillars" area, 27.VI.1992, Shcherbina 121 (MW). Republic of Sakha/Yakutia: Suntar District, Vilyui River $253 \mathrm{~km}$ downstream Ulakhan-Vava, 17.VIII.1958, Kildyushevsky 112/521 (LE); Tomponsky District, Verkhoyansky Mountain System, Sette Daban Range, valley of Vostochnaya Khandyga River, ca. $63^{\circ} 04.3^{\prime} \mathrm{N}$, $137^{\circ} 46.3^{\circ} \mathrm{E}$, 18.VII.2015, Ignatov \& Ignatova 15-680 (MW, MHA). Zabaikalsky Territory: Nerchinsk District, Shivki Settlement, "Shivki Pillars" area, 14.VI.1957, Filin s.n. (MW). Republic of Buryatia: Sayan Mts, Tunka District, V.1902, Elenkin s.n. (LE); Tunka Depression, 13.VIII.1926, Smirnov s.n. (LE). Irkutsk Province: Slyudyanka District, Utulik Railway Station, 1953, anonym (LE). Amurskaya Province: Orochen path from Vozdvizhenskaya to Toko Lake, Tokongro Creek, 31.VII.1911, Prokhorov \& Kuzeneva 178 (LE); Tukuringra Mt. Ridge, between Gilyui and Rakindra Rivers, 23.VII.1915, Prokhorov \& Kuzeneva 124 (LE); Tukuringra Mt. Ridge, 16.VIII.1909, Prokhorov \& Kuzeneva 365 (LE); between Bysa and Selemdzha Rivers, Taldui Mt., 15,IX.1927, Kuzeneva 133 (LE); Zeya State Reserve: Shirokaya Creek mouth, 8.IX.1979, Petelin 132 (MW); Motovaya Creek, 1979, Petelin 23 (MW); Gilyui River near Kamrai Creek mouth, 5.IX.1979, Petelin 129 (MW); Gilyui River 0.5 km dowmstream of Motovaya Creek mouth, 26.VII.1977, Petelin 17 (MW); right slope of Gilyui River valley, $54.2668^{\circ} \mathrm{N}$, 1268531'E, 26.VII.2012, Dudov Br_12_009 (MW).

Differentiation. Habitually, H. kuzenevae is most similar to $H$. czernyadjevae: both species have straight leaves with long, straight or slightly flexuose, densely spinulose hair-points and recurved margins from leaf base to hair-point base. The latter character immediately separates them from $H$. emodica and $H$. mollis, which have only shortly recurved margin at leaf base and flat at the rest part of leaf; at the same time, $H$. ciliata is similar to $H$. kuzenevae and H. czernyadjevae in this respect. The distinction between $H$. kuzenevae and $H$. czernyadjevae is in papillae arrangement: the former species has several branched papillae in each cell, while cells of the latter one are unipapillose. $H$. ciliata with similar multipapillose cells differs from $H$. kuzenevae in often falcate-secund leaves and shorter hair-points (15-25 vs. 35-42\% of leaf length) with less strongly ornamented dorsal suface; moreover, their distribution is contrastiongly different.

Hedwigia emodica var. echinata Ignatova \& Ignatov, Arctoa 26: 000. 2017

Type: Russia, Khabarovsk Territory, Sovgavan District, Botchinsky State Reserve, ca. $48^{\circ} 18^{\prime} \mathrm{N}, 139^{\circ} 35^{\prime} \mathrm{E}$, $362 \mathrm{~m}$ a.s.l., between Solonchakovy Creek and Mulpa River, $1 \mathrm{~km} \mathrm{~N}$ of cordon Teplyi Klyuch, rock outcrops in spruce \& fir forest, on inclined rock surface, 23.VIII.2013, Ignatov \& Ignatova 13-1128 (Holotype MHA, isotypes MW, LE).

Diagnosis. The new variety shares with $H$. emodica var. emodica the following characters: leaf margins narrowly recurved only in basal $1 / 5-1 / 4$ of leaf and flat in distal part; hair-points long; and papillae on adaxial leaf surface 3-4 per cell, branched; their distinctive characters include: (1) falcate-secund leaves with hair-points following leaf curvature in var. echinata vs. always straight leaves with straight hair-points in var. emodica; (2) hairpoints narrower and slightly shorter, constituting 30-35\% vs. 30-53\% of leaf length; (3) margins of hair-ponts with narrow, sharp teeth vs. usually subentire or with few blunt teeth (in rare cases sharp); and (4) dorsal surface of hairpoints covered with simple papillae and long, dense, branched spinulae protruding also at hair-point margins vs. with moderately high papillae and spinulae.

Etymology. Name of the new variety corresponds to strongly ornamented surface of hair-points, covered with high and dense spinulae, that makes them "echinate".

Description. Plants in loose or dense tufts, greyishgreen distally, brownish below. Stems 3-5 cm long, moderately branched. Leaves falcate-secund, rarely almost straight appressed when dry, wedely spreading when wet, $1.5-1.8 \times 0.6-0.7 \mathrm{~mm}$, with width/length ratio $0.35-0.41$, ovate, gradually tapered to the apex, concave; margins narrowly recurved at proximal $1 / 4-1 / 3$; hyaline hairpoints $0.5-0.8 \mathrm{~mm}$ long, constituting $30-35 \%$ of leaf length; margins of hair-points with narrow, sharp, sometimes hooked teeth and protruding spinulae; both surfaces of hair-points covered with simple papillae and long, densely arranged, simple and strongly branched spinulae; apical cell short, finely papillose, truncate, crowned 

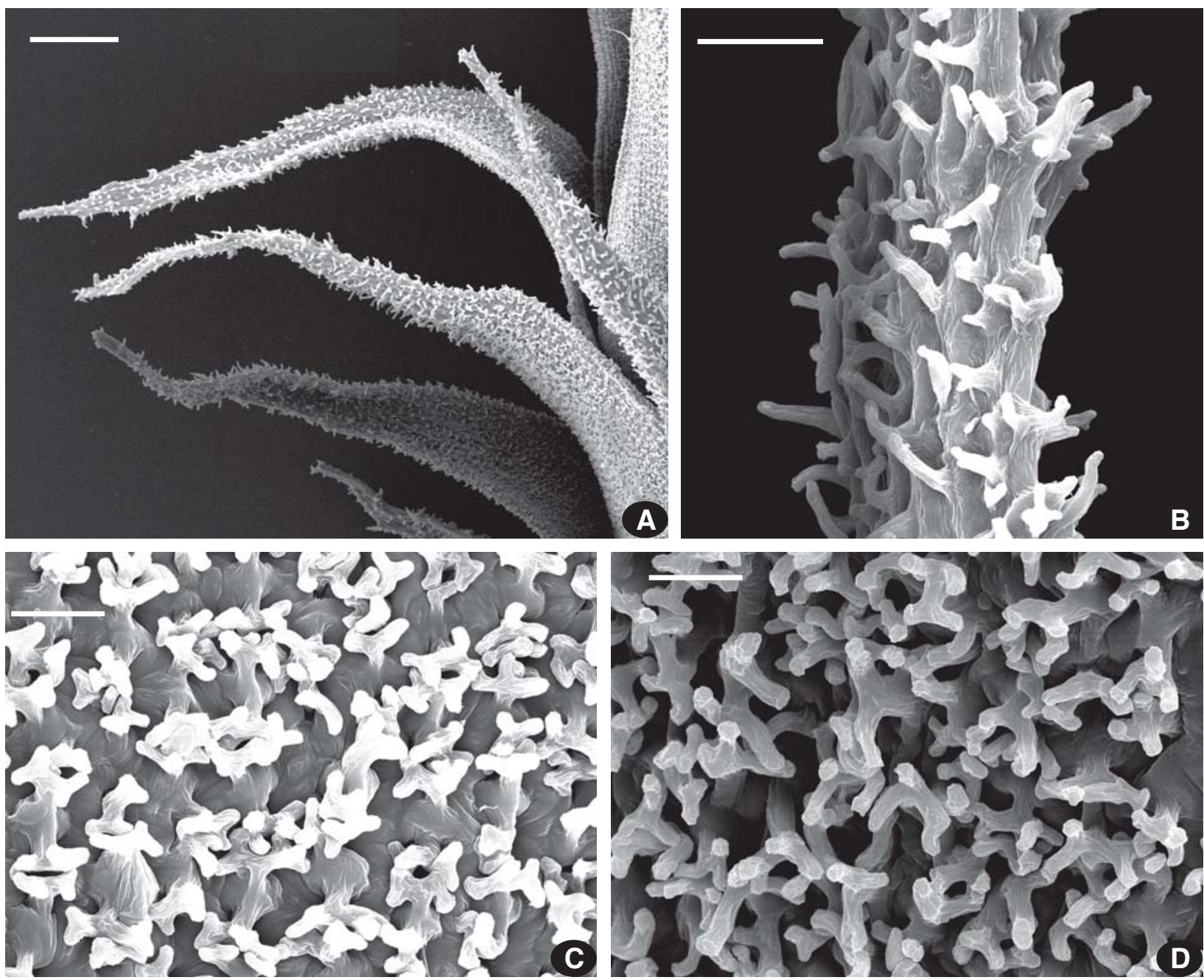

Fig. 5. Hedwigia emodica var. echinata (from holotype). A-D (SEM). A: apical parts of leaves; B: dorsal surface of hair-point, distal portion; C: papillae in mid-leaf on abaxial leaf surface; D: dorsal surface of hair-point, proximal portion. Scale bars: $100 \mu \mathrm{m}$ for $\mathrm{A} ; 20 \mu \mathrm{m}$ for $\mathrm{B} ; 10 \mu \mathrm{m}$ for C. D.

by several sharp papillae; median laminal cells $13-30 \times 11-$ $14 \mu \mathrm{m}$, with thick, sinuose and slighly porose walls, on abaxial surface with 2-3(-4) large, branched papillae per cell, on adaxial surface with 2-3 similar, but smaller papillae per cell; cells in the middle of leaf base linear, 40$80 \times 11-14 \mu \mathrm{m}$, porose, orange-brown, lowermost cells smooth, then gradually becoming papillose upwards, with several simple papillae per cell, rather abruptly transiting into median leaf cells with branched papillae; basal marginal cells quadrate and transversely rectangular, with thin longitudinal and thick and porose transverse walls. Perichaetial leaves oblong, ca. $3 \times 0.8 \mathrm{~mm}$, hyaline hair-points 0.8-1.0 mm, cilia long, numerous. Capsules cup-like or turbinate, $1-1.1 \times 0.8-1.0 \mathrm{~mm}$, widest at the mouth; exothecial cells in the middle part of urn rectangular or shortrectangular, at urn mouth smaller in several rows. Operculum lowly conical, with low central mammilla. Spores 20-25 $\mu \mathrm{m}$, with vermicular ridges on distal surface. $\mathrm{Ca}$ lyptrae hairy in lower portion.

Distribution and ecology. Contrary to the widespread distribution of the type variety, var. emodica is restricted to the southern part of Russian Far East, including Primorsky and Khabarovsk Territory and Amurskaya Province; its westernmost locality is in Buryatia (Bichura River); it was also once collected on Kunashir Island. It grows in forest zone in mountains, up to $1400 \mathrm{~m}$ a.s.1., on dry rocks and cliffs, both shady and exposed, occasionally in places with calcareous bedrocks.

Specimens examined: ASIAN RUSSIA: Primorsky Territory: Shkotovo District, Litovka (Khualaza) Mt., 16.VI.2006, Konovalova s.n. (MHA); Partizansk District, Olkhovaya Peak, $43^{\circ} 21^{\prime} \mathrm{N}, 133^{\circ} 39^{\prime} \mathrm{E}, 1600 \mathrm{~m}$ a.s.1., 3.IX.2006, Ignatov, Ignatova \& Cherdantseva 06-2710, 06-2690 and $1200 \mathrm{~m}$ a.s.1., 062857 (MHA, MW); Lazo District: Sudzukhinsky [Lazovsky] State Reserve, $1300 \mathrm{~m}$ a.s.1., 4.X.1940, Zhudova s.n. (MHA); Elomovsky Creek, Benevskie Waterfalls, 4414'45"N, 13343'2”'E, $630 \mathrm{~m}$ a.s.1., 6.IX.2013, Ignatov \& Ignatova 131353 (MHA); Chuguevka District, upper course of Berezovy Creek, $43^{\circ} 41^{\prime} \mathrm{N}, 134^{\circ} 10^{\prime} \mathrm{E}, 1000 \mathrm{~m}$ a.s.1., 19.VIII.2007, Ignatov 07-235 (MHA); Dalnegorsk District, SW of Krasnorechen-

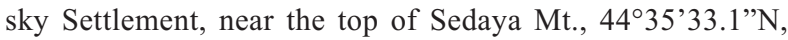
$135^{\circ} 18^{\prime} 35^{\prime \prime} \mathrm{E}, 1340 \mathrm{~m}$ a.s.1., 1.IX.2013, Ignatov, Ignatova \& Malashkina 13-1613 (MHA). Khabarovsk Territory: Sovga- 


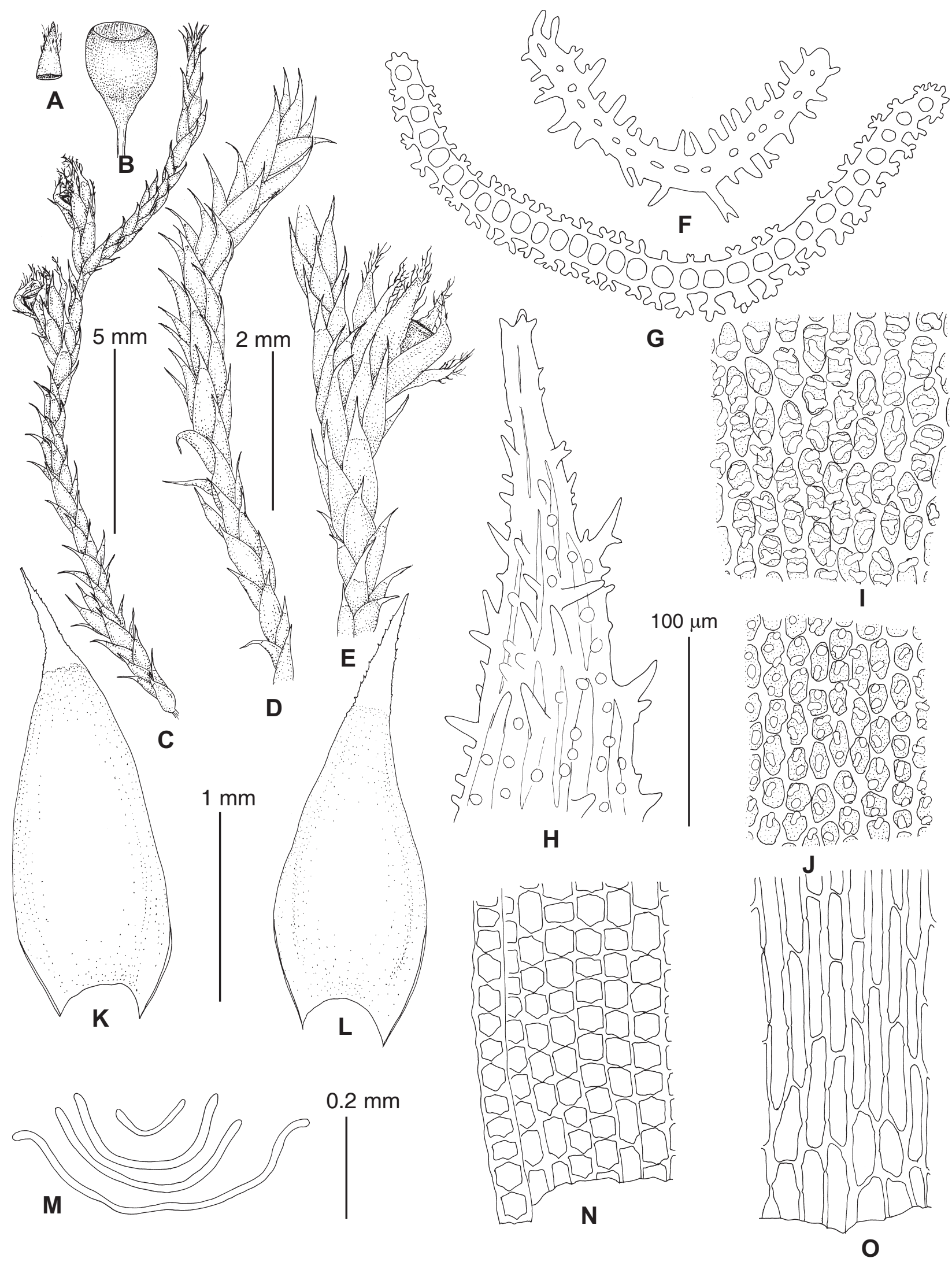

Fig. 6. Hedwigia emodica var. echinata (from holotype). A: calyptra; B: capsule; C-E: habit, dry; F-G, M - leaf transverse sections; H: hair-point; I: median laminal cells om abaxial surface; J: median laminal cells om adaxial surface; $\mathrm{K}-\mathrm{L}$ : leaves;N: basal marginal cells; O: basal cells in the middle of leaf base. Scale bars: $5 \mathrm{~mm}$ for C; $2 \mathrm{~mm}$ for A-B, D-E; $1 \mathrm{~mm}$ for K-L; $0.2 \mathrm{~mm}$ for $\mathrm{M} ; 100 \mu \mathrm{m}$ for $\mathrm{F}-\mathrm{J}, \mathrm{N}-\mathrm{O}$. 
van District, Botchinsky State Reserve, ca. $48^{\circ} 18^{\prime} \mathrm{N}, 139^{\circ} 36^{\prime} \mathrm{E}$, $380 \mathrm{~m}$ a.s.1., 22.VIII.2013, Ignatov \& Ignatova 13-1054, 13878, 13-759, 13-351 (MHA); Khabarovsk District, Bolshekhekhtsirsky State Reserve, Sosninsky Creek, 15.VII.1975, Gambaryan s.n. (MHA); Verkhnebureinsk District, Bureinsky State Reserve:, Pravaya Bureya River, $51^{\circ} 43^{\prime} \mathrm{N}, 134^{\circ} 18^{\prime} \mathrm{E}, 580 \mathrm{~m}$ a.s.1., 27.VIII.1997, Iwatsuki 60698 (MHA); Levaya Bureya River, $51^{\circ} 40^{\prime} \mathrm{N}, 134^{\circ} 22^{\prime} \mathrm{E}, 590 \mathrm{~m}$ a.s.1., 16.VIII.1989, Grigorjeva 89-M-204 (MHA). Sakhalinskaya Province: Kunashir Island, Ruruj Mt., $44^{\circ} 28^{\prime} \mathrm{N}, 146^{\circ} 6^{\prime} \mathrm{E}, 400 \mathrm{~m}$ a.s.1., 30.VIII.2006, Ignatov 06-1119 (MHA). Amurskaya Province: Zeya District, Zeisky State Reserve: Tukuringra Mt. Ridge, slope to Teply Creek, 24.VIN, $127^{\circ}$ II.1977, Gubanov s.n. ((MHA); Shaman Creek, $54.0694 \mathrm{~N}, 127.0742^{\circ} \mathrm{E}, 579 \mathrm{~m}$ a.s.1., 2.VIII.2012, Du-

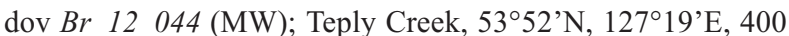
m a.s.1., 11.VIII.1980, L.I. Abramova 107 (MHA); Smirnovsky Creek, 5359'N, $127^{\circ} 24^{\prime}$ E, 350 m a.s.l., 9.VIII.1980, L.I. Abramova 36 (MW). Republic of Buryatia: Bichura District, Bichura River, Afonina 01907 (LE).

Differentiation. For the distinctive characters between var. echinata and var. emodica see the diagnosis. There is some similarity between specimens of $H$. mollis (especially from Altai and Caucasus) and H. emodica var. echinata; some specimens from Baikal Lake area are also difficult to identify due to variability in hair-point length and leaf arrangement. However, in $H$. mollis leaves are only rarely secund, while in var. echinata leaves are conspicuously falcate-secund; hair-points is longer in var. echinata than in H. mollis (30-35\% vs. (17-)23-27($29) \%$ of leaf length; in var. echinata surface of hair-points is covered with papillae and high, dense, branched spinulae almost throughout, excepting apical cell and few adjacent cells, while in $H$. mollis only lower half of hairpoints is densely spinulose and their distal portions bear only sparse, low papillae.

\section{KEY TO IDENTIFICATION OF HEDWIGIA SPECIES IN RUSSIA}

1. Median laminal cells on abaxial side mainly with a single, branched, peltate papilla over each cell .... 2

- Median laminal cells on abaxial side with 2-4 branched, usually not peltate papillae over each cell.. 3

2. Leaf apices straight; median laminal cells strongly incrassate and porose H. czernyadjevae

- Leaf apices reflexed; median laminal cells slightly incrassate, not porose [H. stellata]

3. Plants small; leaves shortly acuminate, secund, with apices following leaf curvature; hyaline hair-points short, usually constituting less than $10 \%$ of leaf length P. nemoralis

- Plants of medium size; leaves gradually narrowed to the apex or rather long acuminate, straight or secund; hyaline hair-points short to very long, usually constituting more than $10 \%$ of leaf length .......... 4

4. Leaf margins narrowly recurved in lower $1 / 4-1 / 2$ of leaf

- Leaf margins \pm widely recurved in lower $2 / 3-3 / 4$ of leaf
5. Leaves straight; hyaline hair-points long, constituting $30-55 \%$ of leaf length, with subentire or bluntly denticulate margins; papillae dense, with thick, round at tips branches, obscuring cell walls

H. emodica var. emodica

- Leaves straight or secund; hyaline hair-points usually shorter, constituting (15-)23-35\% of leaf length, with narrow, sharp teeth at margins; papillae with narrow branches, irregularly arranged or forming longitudinal rows, not obscuring cell walls ........ 6

6. Leaves straight, rarely slightly secund; hyaline hairpoints spreading, moderately papillose, with more or less dense papillae and spinulae in proximal portion and sparse, low papillae in distal part; mid-leaf laminal cells with compact papillae, often formning longitudinal rows; European Russia and west of Southern Siberia H. mollis

- Leaves falcate-secund, hyaline hair-points following leaf curvature, with papillae and high, dense spinulae throughout; mid-leaf laminal cells with irregularly situated papillae; Far East

H. emodica var. echinata

7. Leaves straight or secund; hyaline hair-points moderately papillose; spores (27.5-)30-35(-37.5) $\mu \mathrm{m}$; European Russia ................................... H. ciliata

- Leaves usually straight; hyaline hair-points with dense papillae and spinulae; spores 23-27.5 $\mu \mathrm{m}$; eastern regions of Asian Russia .........H. kuzenevae

\section{ACKNOWLEDGEMENTS}

The work on SEM was performed partially at User Facilities Center of M.V. Lomonosov Moscow State University under financial support of Ministry of Education and Science of Russian Federation. We also thank the curators of herbaria LE and VBGI who made their collections available to us. The study of Ignatova was partially supported by RFBR grant \#16-04-01156, of Kuznetsova by \#15-29-02647, and of Ignatov by the Program of Bioresource Collection Support by FASO RF.

\section{LITERATURE CITED}

BIASUSO, A.B. 2007. The genus Hedwigia (Hedwigiaceae, Bryophyta) in Argentina. - Lindbergia 32: 5-17.

BROTHERUS, V.F. 1925. Musci (Laubmoose) 2. - In: H. G. A. Engler \& K. Prantl (eds.) Nat. Pflanzenfam. (ed. 2). Duncker \& Humblot, Berlin: 1-542.

BUCHBENDER, V., H. HESPANHOL, M. KRUG, C. SÉRGIO, A. SÉNECA, K. MAUL, L. HEDENÄS \& D. QUANDT. 2014. Phylogenetic reconstructions of the Hedwigiaceae reveal cryptic speciation and hybridisation in Hedwigia. - Bryophyte Diversity \& Evolution 36(1): 1-21.

BUCK, W. R. \& D. H. NORRIS. 1996. Hedwigia stellata and H. detonsa (Hedwigiaceae) in North America. - Nova Hedwigia 62: 361-370.

DALTON, N.J., E.M. KUNGU \& D.G. LONG. 2013. A taxonomic revision of Hedwigiaceae Schimp. from the Sino-Himalaya. - Journal of Bryology 35(2): 96-111.

GARDINER, A., M. IGNATOV, S. HUTTUNEN \& A. TROITSKY. 2005 On resurrection of the families Pseudoleskeaceae Schimp. and Pylaisiaceae Schimp. (Musci, Hypnales). - Taxon 54: 651-663.

GOLOBOFF, P.A. 1994. NONA: A Tree Searching Program. - Program and documentation, published by the author, Tucumán, Argentina. 
HALL, T.A. 1999. BioEdit: a user-friendly biological sequence alignment editor and analysis program for Windows 95/98/NT. - Nucleic Acids Symposium Series 41: 95-98.

HEDENÄS, L. 1994. The Hedwigia ciliata complex in Sweden, with notes on the occurrence of the taxa in Fennoscandia. - Journal of Bryology 18: $139-157$.

IGNATOV, M.S., B.C. TAN, Z. IWATSUKI \& E.A. IGNATOVA. 2000. Moss flora of the Upper Bureya River (Russian Far East). - Journal of Hattori Botanical Laboratory 88: 147-178.

IGNATOV, M.S., O.M. AFONINA, E.A. IGNATOVA et al. 2006. Checklist of mosses of East Europe and North Asia. - Arctoa 15: 1-130.
IGNATOVA, E.A., O.I. KUZNETSOVA, V.E. FEDOSOV \& M.S. IGNATOV. 2016. On the genus Hedwigia (Hedwigiaceae, Bryophyta) in Russia. - Arctoa 25(2): 241-277.

NIXON, K.C. 1999a. Winclada (BETA) ver. 0.9.9. - Available at http:// www.cladistics.com/about_winc.html.

NIXON, K.C. 1999b. The parsimony ratchet, a new method for rapid parsimony analysis. - Cladistics 15: 407-414.

RONQUIST, F., M. TESLENKO, P. VAN DER MARK, D.L. AYRES, A DARLING, S. HÖHNA, B. LARGET, L. LIU, M.A. SUCHARD \& J.P. HUELSENBECK. 2012. MrBayes 3.2: Efficient Bayesian phylogenetic inference and model choice across a large model space. - Systematic Biology 61: 539-542.

APPENDIX 1. GenBank accession numbers (newly generated sequences are boldfaced and include specimen vaucher data).

Braunia alopecura LN714249; Hedwigia ciliata Belarus KY358099; H. ciliata Germany LN714255; H. ciliata Moscow KY358105; H. ciliata Murmansk KY358096; $H$. ciliata Orel KY358095; H. ciliata Pskov KY358113; H. ciliata St Petersburg KY358097; $H$. ciliata Sweden 1 LN714262; H. ciliata Sweden 2 LN714263; H. ciliata Sweden 3 LN714264; H. ciliata Tver KY358108; $H$. czernyadjevae Khabarovsk KY358117; H. czernyadjevae Yakutia KY358116; H. czernyadjevae Transbaikalia $1 \mathrm{KY} 358118 ;$; czernyadjevae Transbaikalia 2 KY358115; H. detonsa USA LN714254; H. emodica var. echinata Amurskaya KY358133 (sub. H. sp.); H. emodica var. echinata Khabarovsk $1 \mathrm{KY} 358131$ (sub. H. sp.); H. emodica var. echinata Russia, Khabarovsk Bureya, Ignatov 97-538 (MHA) OK1772 MG701917; H. emodica var. echinata Primorsky 1 KY358129 (sub. H. sp.); H. emodica var. echinata Primorsky 2 KY358132 (sub. H. sp.); H. emodica var. echinata, Russia, Primorsky, Benevskie Waterfalls, Ignatov and Ignatova 13-1353 (MHA), OK1588 MG701916; $H$. emodica Amurskaya KY358089; H. emodica Dagestan KY358104; $H$. emodica Evenkia 1402 KY358101; H. emodica Kabardino Balkaria KY358125; H. emodica Kamchatka KY358124; H. emodica Karachay Cherkessiya KY358122; H. emodica Khabarovsk Botchi KY358126; H. emodica Perm KY358111; H. emodica Primorsky KY358127; H. emodica Taimyr 1 KY358088; H. emodica Taimyr 2 KY358103; H. emodica Russia, Transbaikalia 1, 14-8-2011 Afonina \# 27-11 (MHA ex LE) OK1589 MG701914; H. emodica Russia, Transbaikalia 2, Bichura, Afonina 01907 (MHA ex LE) OK 1604 MG701915; H. emodica Transbaikalia 3 KY358080; H. emodica Yakutia KY358123; H. kuzenevae Amurskaya Russia, Amurskaya Province, Zeya, Dudov \#Br-12-109 (MW) OK 1590 MG701918; H. kuzenevae Russia, Evenkiya, Shcherbina s.n., 27.06.1992, (MW9042885) OK1600 MG701919; H. kuzenevae Russia, Zabaikalsky, 13 July 2012 Czernyadjeva \# 2-12 (MHA ex LE) OK 1761 MG701920; H. kuzenevae Amurskaya 1590 XXXXXX; H. kuzenevae Evenkiya 1600 XXXXXX; H. kuzenevae Transbaikalia 1761 XXXXXX; H. mollis Altai KY358083; H. mollis Bashkortostan KY358102; H. mollis Karachay Cherkessia KY358082; H. mollis Karelia KY358081; H. mollis Kursk KY358110; H. mollis Murmansk KY358091; H. mollis Orenburg KY358079; H. mollis Tula KY358090; H. nemoralis China Anhui China Anhui, Ignatov 054019 (MHA) OK1601 MG701913; H. nemoralis Georgia KY358093; H. nemoralis Krasnodar KY358084; H. nemoralis Primorsky 1320 KY358087; H. nemoralis Transbaikalia KY358086; H. nemoralis USA Missouri KY358109; H. stellata Germany 1 LN714267; H. stellata Germany 2 LN714268; H. stellata Sweden LN714269; H. stellata Kenya LN714240 (sub H. ciliata); H. striata Portugal LN714266; H. striata Spain LN714265. 